\title{
Morphological and functional abnormality in the spiny butterfly ray Gymnura altavela

Krupskaya Narváez ${ }^{1,2^{*}}$ and Filip Osaer ${ }^{1,2}$

\begin{abstract}
Background: A variety of abnormalities have been described for sharks, rays and skates across different ecoregions. Morphological and functional anomalies in these species, however, were not yet documented in distributions from the Canary Islands, the spiny butterfly ray Gymnura altavela (Linnaeus, 1758) and from in situ observations. The aim of the present study is to fill these knowledge gaps.

Results: A female spiny butterfly ray G. altavela with an unfused anterior part of the right pectoral fin to the neurocranium was observed in the port of Sardina del Norte (Gran Canaria Island) during a visual scuba diving census.

Conclusion: The size and the observation of the activities swimming, burying and preying confirmed the adaption of the specimen for the anomaly and underdeveloped electrosensory system in its survival. The limited knowledge of teratogens and their triggering factors, and the striking similarity with an anomaly reported for G. poecilura (Shaw, 1804) from South India, suggest genetic expression aberrations or mechanical obstructions during gestation as origin for the disorder.
\end{abstract}

Keywords: Gymnuridae, Elasmobranch, Congenital disorder, Malformation, Adaption, Batoids, Swimming behaviour, Sardina del Norte, Canary Islands, Temperate Northern Atlantic

\section{Background}

Occurrences of abnormalities have been widely reported for various elasmobranch species in different ecoregions. Records for skates and rays include bicephalism in the Magdalena Transition (Castro Aguirre and Torres Villegas 1979) and Basian (Guida et al. 2014), hermaphrodism in the Ionian Sea (Dalù et al. 2003), aberrant appendages in the Patagonian Shelf (Deli-Antoni et al. 2012) and in the North Sea (Ellis 2005), lack of gill-slit and underweight in brackish waters from the Tunisian Plateau (El Kamel et al. 2009), absent tip of the snout in the South European Atlantic Shelf (Forster 1967), incomplete rostrum in the Southwestern Caribbean (Ramírez-Hernandez et al. 2011) and albinism in the Southern Gulf of Mexico (Wakida-Kusunoki 2015).

Failure of the anterior part of the pectoral fin to join with the head during embryonic development are not

\footnotetext{
* Correspondence: Krupska@ElasmoCan.org

${ }^{1}$ ElasmoCan, Asociación Canaria para la Investigación y Conservación de los Elasmobranquios, 35001 Las Palmas de Gran Canaria, Spain

${ }^{2}$ Fundación Colombiana para la Investigación y Conservación de Tiburones y Rayas, SQUALUS Carrera 60A No 11-39, Cali, Colombia
}

rare in batoids (Tortonese 1956) and have been reported in, e.g the Adriatic Sea (Valle 1931), the Virginian (Gudger 1933), the Sea of Japan (Honma and Sugihara 1971), the Humboldtian (Lamilla et al. 1995), the Aegean Sea (Metin et al. 2009), Southeastern Brazil (RibeiroPrado et al. 2008), the Tunisian Plateau (Mnasri et al. 2010) and the Panama Bight (Mejía-Falla et al. 2011).

Congenital abnormalities for the genus Gymnura (Hasselt, 1823) have been reported in the smooth butterfly ray Gymnura micrura (Bloch \& Schneider, 1801) from the Amazonia (Nunes and Piorski 2009), and the long-tailed butterfly ray Gymnura poecilura (Shaw, 1804) from South India and Sri Lanka (Bennet 1964; Day 1878; Easwaran 1967; Suresh and Raffi 2012) (Table 1).

Reports of cases with disorders in elasmobranch species from the Canary Islands, the spiny butterfly ray Gymnura altavela (Linnaeus, 1758) and from in situ observations were not collected so far. In this sense, the present communication is a novel report of an abnormality in an elasmobranch species in this region based 
Table 1 Summary of observed anomalies in the genus Gymnura. Realm as defined by Spalding et al. (2007)

\begin{tabular}{|c|c|c|c|c|c|c|c|}
\hline Species & Anomaly description & $\begin{array}{l}\text { Disc width } \\
(\mathrm{cm})\end{array}$ & $\begin{array}{l}\text { Depth } \\
(\mathrm{m})\end{array}$ & Sex & $\begin{array}{l}\text { Number of } \\
\text { cases }\end{array}$ & Realm & Study \\
\hline $\begin{array}{l}\text { Gymnura } \\
\text { micrura }\end{array}$ & Dorsal fold on the tail & $17.8-21.7$ & $8-25$ & - & 2 & Tropical Atlantic & $\begin{array}{l}\text { Nunes \& Piorski } \\
\text { (2009) }\end{array}$ \\
\hline $\begin{array}{l}\text { Gymnura } \\
\text { poecilura }\end{array}$ & $\begin{array}{l}\text { Unfused anterior part of both pectoral } \\
\text { fins to the neurocranium }\end{array}$ & 15.2 & - & - & 1 & Western Indo-Pacific & Day (1878) \\
\hline $\begin{array}{l}\text { Gymnura } \\
\text { poecilura }\end{array}$ & $\begin{array}{l}\text { Unfused anterior part of both pectoral } \\
\text { fins to the neurocranium }\end{array}$ & 8.9 & - & - & 1 & Western Indo-Pacific & Bennet (1964) \\
\hline $\begin{array}{l}\text { Gymnura } \\
\text { poecilura }\end{array}$ & $\begin{array}{l}\text { Unfused anterior part of both pectoral } \\
\text { fins to the neurocranium }\end{array}$ & 22.5 & $8-18$ & Male & 1 & Western Indo-Pacific & Easwaran (1967) \\
\hline $\begin{array}{l}\text { Gymnura } \\
\text { poecilura }\end{array}$ & $\begin{array}{l}\text { Unfused anterior part of the right pectoral } \\
\text { fin to the neurocranium }\end{array}$ & 47.5 & Coastal & Female & 1 & Western Indo-Pacific & $\begin{array}{l}\text { Suresh \& Raffi } \\
\text { (2012) }\end{array}$ \\
\hline $\begin{array}{l}\text { Gymnura } \\
\text { altavela }\end{array}$ & $\begin{array}{l}\text { Unfused anterior part of the right pectoral } \\
\text { fin to the neurocranium }\end{array}$ & 137 & $8-13$ & Female & 1 & $\begin{array}{l}\text { Temperate Northern } \\
\text { Atlantic }\end{array}$ & $\begin{array}{l}\text { The present } \\
\text { study }\end{array}$ \\
\hline
\end{tabular}

on data from G. altavela during a visual scuba diving census.

Gymnura altavela is distributed from tropical to warm temperate continental shelf waters on both sides of the Atlantic Ocean, including the Mediterranean Sea, the Black Sea and the Madeira and Canary Islands. Maximum size is assumed to be $200 \mathrm{~cm}$ disc width. Its limiting life history, patchy and discontinuous distribution, and habitat dependent characteristics make it intrinsically vulnerable to population depletion. This species was classified as 'Vulnerable' on the basis of a suspected continuing decline of at least $30 \%$ (Vooren et al. 2007). In the Canary Islands, G. altavela is distributed over the complete archipelago, being more abundant in the eastern islands (Bravo de Laguna and Escánez 1975).

\section{Materials and methods}

On 22 and 28 July 2007, and 6 July 2008, during underwater visual census in the port of Sardina del Norte $\left(28^{\circ}\right.$ $09^{\prime} \mathrm{N}$ and $15^{\circ} 41^{\prime} \mathrm{O}$ ), Gran Canaria Island, an unusual female individual G. altavela with $137 \mathrm{~cm}$ disc width was observed. Size, activity, depth, water temperature and behaviour were recorded.

\section{Results}

The interior margin of the specimens' right pectoral fin was detached from the braincase and the rostral ridge. It appeared as a free lobe slightly projecting forward from the disc plane, with the lateral margin pointed towards the exterior margin of the disc. The anterior margin of the disc was incomplete from the rostral ridge up to the lateral extreme of the spiracle. At the proximal end, the disc was absent up to the neurocranium, extending from the rostral ridge to behind the posterior margin of the spiracle. Epidermis pigmentation was absent at the proximal part of the lobe with a similar appearance, in colour and texture, of the white epidermis from the ventral side (Fig. 1).
All observations occurred in the same area between 8.0 and $10.7 \mathrm{~m}$ depth and a water temperature of $21{ }^{\circ} \mathrm{C}$. The individual was found buried in the sand during all three encounters. During the first observation, the individual was startled by an angel shark Squatina squatina (Linnaeus, 1758) and left swimming (Additional file 1: Movie S1). Swimming was observed between 0.1 and $2 \mathrm{~m}$ above sand -and rock substrate. During swimming, the snout position was slightly pointed upwards, compared to what was observed in other individuals of $G$. altavela, and the posterior end of the lobe pointed downwards. During the third observation, a successful predation event was observed on the bogue Boops boops (Linnaeus, 1758) of approximately $10 \mathrm{~cm}$ total length, which were very abundant in the area. It was only possible to measure the individual, which was very susceptible to the authors' presence, during the second

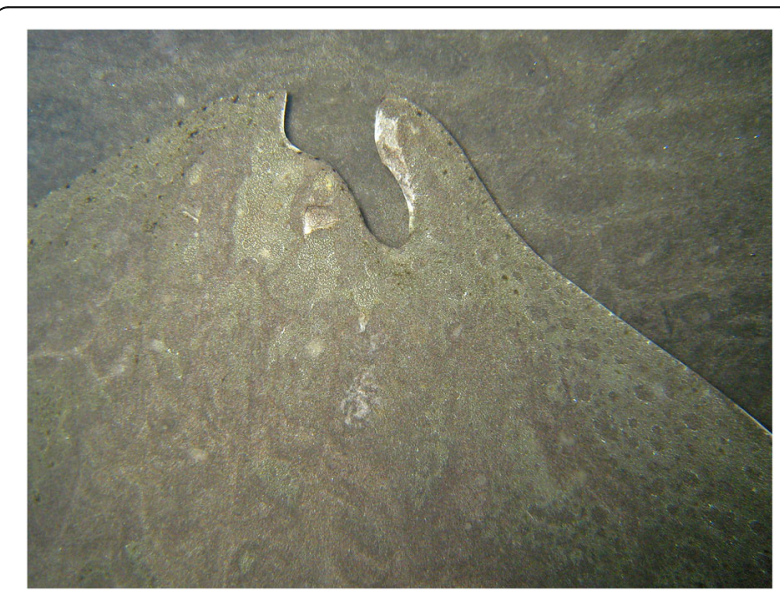

Fig. 1 Gymnura altavela (Linnaeus, 1758), female of $137 \mathrm{~cm}$ disc width with a morphological and functional abnormality of the right anterior disc, observed in the port of Sardina del Norte, Gran Canaria Island 
encounter. No significant changes were observed on the anomaly between the observations of 2007 and 2008.

\section{Discussion}

The present communication is not only the first description of an elasmobranch disorder in the Canary Archipelago, but also a novel report for recording the first anomaly in G. altavela, and observing the individual in its natural habitat on several occasions, with different activities, and with a resighting after one year. Numerous anomaly reports were obtained from catch landings of free swimming elasmobranchs (Blanco-Parra and Niño-Torres 2011; Capapé et al. 2015a; Capapé et al. 2015b; Castro Aguirre and Torres Villegas 1979; Dalù et al. 2003; El Kamel et al. 2009; Forster 1967; Gudger 1933; Honma and Sugihara 1971; Metin et al. 2009; Mnasri et al. 2010; Moore 2015; Nunes and Piorski 2009; Orlov 2011; Ramírez-Hernandez et al. 2011; Ribeiro-Prado et al. 2008; Sandoval-Castillo et al. 2006; dos Santos and Gadig 2014; Valle 1931), but none of them observing the specimen actively in its environment.

Five out of the six reported anomaly cases in the genus Gymnura describe unfused pectoral fins. Four of these cases are reports for G. poecilura in the same ecoregion with individuals between 8.9 and $47.5 \mathrm{~cm}$ disc width, of which three had both pectoral fins unfused. The latter all present a disc width below the reported size at birth by James (1966) of $23.7-25.6 \mathrm{~cm}$. Presumably, the smallest individual described by Bennet (1964) might have been confused with an embryo in normal development. The instance reported in the present study is evidently the largest observed individual in the genus so far (Table 1).

The low numbers of anomaly reports known in the genus Gymnura suggests they are less prone to different types of disorders. However it should be considered that these species also receive less attention from researchers in scientific production compared to other elasmobranch species. Yet, this is the only observed case of this species by the authors during systematic and periodic underwater census since 2006 in this area and others in the Canary Archipelago, with the main effort in Gran Canaria.

The partial lack of the disc in way of the rostrum will affect locomotion, manoeuvrability, prey detection, prey capture efficiency and burial that will require specialized adaptions and a higher energy budget for survival compared to individuals with a complete disc. Locomotion and manoeuvrability will be affected by the different shaped pectoral fin. The radiographic image in the study of Suresh and Raffi (2012) showed that the pectoral fin propterygium was not curved towards the neurocranium in way of the splanchnocranium. Instead, a bigger radius was observed pointing the propterygium towards the tip of the snout. The individual will also have a considerable disadvantage in detecting and trapping a prey with the anterior part of its disc, and for burying in the sand. By inferring from the descriptions of Jordan (2008) and Maruska (2001), the electrosensory system in the anterior part of the disc will be partly absent and underdeveloped. In spite of the above-mentioned hindrances to develop activities, instances while preying, swimming and burying were recorded. The size of the individual and its ability to compete with other elasmobranch species for the same food resource indicate the ability to compensate for the malformation in its survival. Even though, the individual will still be less competent compared to others.

The lack of fusing of the pectoral fins is a congenital disorder as the attachment of the pectoral fins to the head is a secondary development for embryos in batoids (Bigelow and Schroeder 1953). Genetic disorders were also suggested as underlying cause (Tortonese 1956). The present report is interesting in view of a similar description for such a pectoral fin anomaly in G. poecilura by Suresh and Raffi (2012). The analogy of the two cases is prominent in shape, location, and texture. Some difference was observed in more protruding, and absent pigmentation patch, of the lobe in the latter study. Given the striking similarity of the condition between G. poecilura (Suresh and Raffi 2012) and G. altavela from the present study in the Western Indo-Pacific and the Temperate Northern Atlantic, respectively, and the lack of antecedents of elasmobranch anomalies in the Canary Islands, the authors advance genetic expression aberrations or mechanical obstruction during the embryo development as possible reasons for the anomaly. It is not clear however whether this disorder is either or not triggered by alterations in the marine environment. There is no conclusive data to define the cause of the anomaly or to conclude that embryos with a similar disorder will have the same survival success based on the occurrence of a single individual.

Morphologic deformations, and especially congenital disorders, are poorly understood in elasmobranchs. Castro Aguirre and Torres Villegas (1979) pointed out early the lack of research corroborating teratogens that cause congenital disorders. The need for more detailed studies on abnormal embryos linked to the embryological, genetic and ecotoxicological approaches as highlighted by dos Santos and Gadig (2014) is underlined with this case.

\section{Additional file}

\footnotetext{
Additional file 1: Movie S1. Video recording in the port of Sardina del Norte (Gran Canaria) of a female Gymnura altavela (Linnaeus, 1758) (137 cm disc width) with a morphological and functional abnormality of the right anterior disc, startled by an angelshark Squatina squatina (Linnaeus, 1758). (MP4 27241 kb)
} 


\section{Funding}

This study was supported by the Shark Foundation.

\section{Availability of data and materials}

The dataset supporting the conclusions of this article is included within the article as photographs, video and geographical coordinates.

\section{Authors' contributions}

Both authors conceived the study, participated in the field data collection, data analysis, background analysis, preparation of the manuscript, and read and approved the final manuscript.

\section{Competing interests}

The authors declare that they have no competing interests.

\section{Consent for publication}

Not applicable.

\section{Ethics approval and consent to participate}

Not applicable

Received: 25 September 2016 Accepted: 27 September 2016

Published online: 18 October 2016

\section{References}

Bennet SP. On an abnormal ray from Vizhinjam. J Mar Biol Assoc India. 1964;6: 316-7.

Bigelow HB, Schroeder WC. Fishes of the Western North Atlantic Part 2 Sawfishes, Guitarfishes, Skates and Rays. New Haven: Sears Foundation for Marine Research, Yale University; 1953.

Blanco-Parra MP, Niño-Torres CA. Morphological abnormality in a diamond stingray, Dasyatis dipterura (Jordan \& Gilbert, 1880)(Chondrichthyes: Dasyatidae), from the Gulf of California. Mexico Cah Biol Mar. 2011; 52(3):357-60

Bravo de Laguna J, Escánez J. Informe sobre las posibilidades pesqueras de elasmobranquios en el Archipiélago Canario. Publicaciones Técnicas Dirección Gen. Pesca Maritima. 1975:11:169-92.

Capapé C, Ali M, Saad A, Alkusairy H, Reynaud C. Atypical characteristics in the longnosed skate Dipturus oxyrinchus (Linnaeus, 1758) from the coast of Syria (Eastern Mediterranean). Thalass Salentina. 2015a;37:71-80.

Capapé C, Ali M, Saad A, Reynaud C. Tail abnormalities in thornback ray Raja clavata (Chondrichthyes: Rajidae) from the coast of Syria (eastern Mediterranean). Cah Biol Mar. 2015b;56(2):155-61.

Castro Aguirre JL, Torres Villegas JR. Sobre un caso de bicefalia funcional en Rhinoptera steindachneri Evermann y Jenkins (Chondricthys, Elasmobranchii, Batoidei), capturado en la costa occidental de Baja California. México Cienc Mar. 1979;6:27-41.

Dalù M, Consalvo GC, Romanelli M. A hermaphrodite specimen of Torpedo torpedo (Chondrichthyes, Torpedinidae). Biol Mar Mediterr. 2003;10:792-4.

Day F. The fishes of India; being a natural history of the fishes known to inhabit the seas and fresh waters of India, Burma, and Ceylon. London: Bernard Quaritch Ltd; 1878

Deli-Antoni MYD, Delpiani GE, Delpiani SM, Mabragana E. Díaz de Astarloa JMD. An aberrant extra fin in Zearaja chilensis (Chondrichthyes: Rajidae). Cybium. 2012:36(2):403-5.

dos Santos CMH, Gadig OBF. Abnormal embryos of sharpnose sharks, Rhizoprionodon porosus and Rhizoprionodon Ialandii (Elasmobranchii: Carcharhinidae), from Brazilian coast, western South Atlantic. Mar Biodivers Rec. 2014:7:e55.

Easwaran CR. On an abnormal ray from the Gulf of Kutch. J Mar Biol Assoc India. 1967;9(1):198-200.

El Kamel O, Mnasri N, Boumaiza M, Capape C. Atypical abnormality in a common torpedo, Torpedo torpedo (Chondrichthyes: Torpedinidae) from the Lagoon of Bizerte (northern Tunisia, central Mediterranean). Cah Biol Mar. 2009;50(1):97-101.

Ellis JR. An abnormal thornback ray Raja clavata with additional pectoral fins. Suffolk Nat Hist. 2005;41:31-7.

Forster GR. A note on two rays lacking part of the snout. J Mar Biol Assoc U K. 1967:47(3):499-500

Gudger EW. A second barn-door skate, Raja stabuliforis, with pectorals nonadherent to the head. Am Mus Novit. 1933;600:1-10.
Guida L, Walker TI, Reina RD. First record of a bicephalic chondrichthyan found in Australian waters; the southern fiddler ray, Trygonorrhina dumerilii (Chondrichthyes: Rhinobatidae). Mar Freshw Res. 2014;65(5):396-9.

Honma Y, Sugihara C. A stingray, Dasyatis akajaei, with aberrant pectoral fins from the Japan Sea. Japan J Ichthyol. 1971;18(1):187-9.

James P. Notes on the biology and fishery of the butterfly ray, Gymnura poecilura (Shaw) from the Palk Bay and Gulf of Mannar. Indian J Fish. 1966;13(1 \& 2): 150-7.

Jordan LK. Comparative morphology of stingray lateral line canal and electrosensory systems. J Morphol. 2008;269(11):1325-39.

Lamilla J, Pequeño G, Kong I. Dasyatis brevis (Garman, 1880) second species of Dasyatidae registered for Chile (Chondrichthyes, Myliobatiformes). Estudios Oceanológicos. 1995:14:23-7.

Maruska KP. Morphology of the Mechanosensory Lateral Line System in Elasmobranch Fishes: Ecological and Behavioral Considerations. Environ Biol Fishes. 2001;60(1-3):47-75.

Mejía-Falla PA, Navia AF, Muñoz LA. First record of morphological abnormality in embryos of Urotrygon rogersi (Jordan \&amp; Starks, 1895) (Myliobatiformes: Urotrygonidae) in the Tropical Eastern Pacific. Lat Am J Aquat Res. 2011;39(1):184-8

Metin G, Illkyaz AT, Kinacigil HT. Morphologic deformation in a ray: a case report. Turk J Vet Anim Sci. 2009:33(3):261-3.

Mnasri N, El Kamel O, Boumaïza M, Ben Amor MB, Reynaud C, Capapé C. Morphological abnormalities in two batoid species (Chondrichthyes) from northern Tunisian waters (central Mediterranean). Ann Ser Hist Nat. 2010;20:181-90.

Moore ABM. Morphological abnormalities in elasmobranchs: abnormal elasmobranchs from the gulf. J Fish Biol. 2015;87(2):465-71.

Nunes JLS, Piorski NM. A dorsal fold in Gymnura micrura (Bloch and Scheneider, 1801) (Chondrichthyes: Gymnuridae). Braz Arch Biol Technol. 2009:52(2):479-82.

Orlov AM. Record of a tailless Richardson's ray Bathyraja richardsoni (Garrick, 1961)(Rajiformes: Arhynchobatidae) caught off the Mid-Atlantic ridge. PanAm J Aquat Sci. 2011;6(3):232-6.

Ramírez-Hernandez A, Palacios-Barreto P, Diego Gaitan-Espitia J, Reyes F, Ramírez J. Morphological abnormality in the longnose stingray Dasyatis guttata (Myliobatiformes: Dasyatidae) in the Colombian Caribbean. Cybium. 2011;35: 79-80

Ribeiro-Prado CC, Oddone MC, Gonzalez MB, Amorim AF, Capapé C. Morphological abnormalities in skates and rays (Chondrichthyes) from off southeastern Brazil. Arq Ciênc Mar. 2008:41:21-8.

Sandoval-Castillo J, Mariano-Meléndez E, Villavicencio-Garayzar C. New records of albinism in two elasmobranchs: the tiger shark Galeocerdo cuvier and the giant electric ray Narcine entemedor. Cybium. 2006:30(2):191-2.

Spalding MD, Fox HE, Allen GR, Davidson N, Ferdaña ZA, Finlayson M, et al. Marine Ecoregions of the World: A Bioregionalization of Coastal and Shelf Areas. BioScience. 2007;57(7):573-83.

Suresh TV, Raffi SM. Pectoral fin anomalies in the long-tailed butterfly ray, Gymnura poecilura collected from Nagapattinam coastal waters, south-east coast of India. Mar Biodivers Rec. 2012;5:e96.

Tortonese E. Fauna d'Italia. Vol. II. Leptocardia, Ciclostomata, Selachii. Bologna: Edizioni Calderini; 1956.

Valle A. Contributo alla teratologia dei Crostacei e dei Pesci Adriatici. Atti Mus Civ Stör Nat Trieste. 1931;11(2):360-3.

Vooren CM, Piercy AN, Snelson FS, Grubbs RD, Notarbartolo di Sciara G, Serena S. Gymnura altavela. In: IUCN 2008. IUCN Red List of Threatened Species. Version 2015.2. 2007. www.iucnredlist.org. Accessed 12 Aug 2015.

Wakida-Kusunoki AT. First record of total albinism in southern stingray Dasyatis americana. Rev Biol Mar Oceanogr. 2015;50(1):135-9. 